\title{
Prospective of Provision of Dairy Products for the Population of Ukraine
}

\author{
Anna Slobodianyk ${ }^{1}$, and George Abuselidze ${ }^{2, *}$ \\ ${ }^{1}$ National University of Life and Environmental Science of Ukraine, 03041, 15, Heroiv Oborony St, \\ Kyiv, Ukraine \\ ${ }^{2}$ Batumi Shota Rustaveli State University, 6010, 35, Ninoshvili str., Batumi, Georgia
}

\begin{abstract}
The article covers the general theoretical regulations of supply of the population of Ukraine with the dairy products. The authors emphasize the matters of supply of material and technical recourses, achievement of just relations in supply system upon transfer of ownership along the walkway of raw materials and further of the ready product to customer. Purposefulness of application of the model of supply of the population of Ukraine with the dairy products developed by the authors is proved. The essence of this model consists in the closed cycle: production - sale - incomes - recourses market (and land market) - consumption export - import - employment level - production. We reasoned direct relation of reduction of livestock population to rise of food price, when in the chain of production, processing and trade the incomes aggregate in the last stages of the chain and the initial goods producers sustain losses. The authors come to conclusion that creation of family farms will be successful providing that they integrate into cooperatives maintaining the closed cycle of production, processing and sale of ready products and as a result, the structural improvements will cause increase of profits and rise of employment of rural population.
\end{abstract}

\section{Introduction}

Use The problem of provision of population with food becomes complicated worldwide, because of population upsurge, uneven distribution of agricultural lands and different density of population in the countries. In Ukraine the food problem grew, especially in respect of dairy products due to ignoring of various interconnected domestic and foreign problems, namely in the part of structural reorganization of the agrarian sector and determination of its place in the international division of labour. Dairy cattle-breeding which worldwide is considered an economy-stabilizing factor suffers depression in Ukraine. From year to year livestock reduces and total output of milk correspondingly drops. In the regional scale the problems are the same, as the population of Ukraine produces milk mainly for domestic consumption. Without development of the measures for ceasing of this negative tendency consideration of the problem of food safety becomes pointless.

*Corresponding author abuseri@mail.ru / abuselize@gmail.com 
Theoretical and practical problems of provision of food for population as a forming part of food safety has been researched by such scientists, as B.P.Andreychuk, P.S.Berezovsky, V.I.Boyko, V.I.Vlasov, V.M.Geets, A.I.Goychuk, M.M.Ilchuk, M.M.Kalinchik, S.M.Kvasha, O.Kochetkov, A.S.Lisetsky, I.I.Lukinov, T.L.Mosnenska, M.K.Parkhomets, B.I.Baskhaver, A.M.Stelmaschuk, P.T.Sabluk, V.V.Iurshinin, O.M.Spichak and others [14].

But they mainly discussed the problems of theoretical grounds of definitions of "provision of food" and "food safety" and their calculation indexes and indicators.

These are the results of the economic activity of such complex industrial system as dairy subcomplex. At the same time insufficiently are studied the problems concerning start of production and further turnover of cost in the process of reproduction of this subcomplex on the stages of production, distribution, redistribution, final consumption.

The aim of this research includes system grounding of the variants of possible solution of the harmonized relations in the dairy subcomplex as a basis for cessation of decline of the sector and development of the ways for improvement of provision of the population of Ukraine with milk and dairy.

\section{Methods}

For the purpose of this article, we used such methods of research, as an abstract-logical method - for generalization of the theoretical and applied aspects of the results of food safety; statistic grouping method - for research of dependence of milk price on stocking in Ukraine, structural changes in specialization on the global level and how it affects development of agriculture; index method - for correlation of time series of prices, aggregate profit of population and level of consumption of dairy, graphic method - for visual demonstration of the tendencies of mild production, aggregate profits and share of food expenses; economic-mathematic method - for balance calculations through the "inputoutput" model for distribution of cost of milk as a raw material in dairy factory assortment and determination of price level depending on final product structure.

\section{Results and discussion}

Functioning of the food market is a complex process including production, transportation, processing, storage and retail trade by the ultimate consumer. At the same time it is accompanying with solving of the matters of supply of the system with material and technical recourses, achievement of the just relations therein in the course of changes of ownership on the walkway of raw materials and further, of the ready product to consumers. All these processes attended by the economic relations in such integrated production as dairy subcomplex may be easily described with the "input-output" model which is formed up by the balance methodology. It allows to solve the wide range of tasks for achievement of pricing balance in the system and, consequently in the mutually beneficial relations. Just production safety is related to optimization of the mutual relations between the participants of the market cooperation. But the indicators of production safety play the role of control indexes of tendency to improvement of the state of economy and correspondingly to provision of the population with food.

The foreign countries use the economic and mathematic models and methods for forecasting of development of the world food market. Organization for Economic Cooperation and Development (OECD) has developed the international models system Aglink-Cosimo which provides 10-year forecasting of the variants of development of the world food recourses, namely: indexes of total output of food production, demand and supply of food, extent of provision of the population with the essential food and above all, 
the equilibrium prices in the world markets for 19 kinds of the agricultural products. This models system includes 10800 econometric equations and modules (complies with forecasting demands of 39 countries and 19 regions) based on the time series of indicators of food markets development. At the territory of Ukraine the mathematic models of the agricultural production are also developed and scenario calculations based on them allow assessing of food safety together with the optimized production indicators. For example, P. M. Gritsiuk in his article "Prospective of Grain Production and grain exportation from Ukraine in the Context of the World Food Crisis" describes the results of application of the mathematic models in forecasting of development of the grain production sector to equilibrium breakdown into export, forage and consumption as an index of food safety [5].

That is why, food provision on the regional level (in case of lack of rational distribution of production between the regions) is described according to this index. When the integral indexes of food safety on the national level are low (insufficient), the regions cannot independently solve the problems of food safety. Economic growth in the country promotes investment, economy renewal, improvement of the structure of economy (in agriculture according to the principles of the relative references). This phenomenon - impact of the structural changes of economy on its development and correspondingly on food safety- was first researched by the Nobel Prize Laureate Simon Kuznets. He found through the data base of the statistic indexes of development of the world countries economies that growth of GDP is mainly caused with changes of economy structure with the corresponding progress: final production structure, employment structure, amount of and structure of incomes, international flows of goods, labour force and capital [2]. Structure and mutual relations in national economy can be mostly effectively described with the "input-output" model which is developed as per balance methodology. For clear revealing of interrelations in dairy subcomplex and how their final products structure affects their profitability and prices of final consumption, we have developed the generalizing flow chart of supply of the population of Ukraine with food (at the macro-level) (Fig. 1).

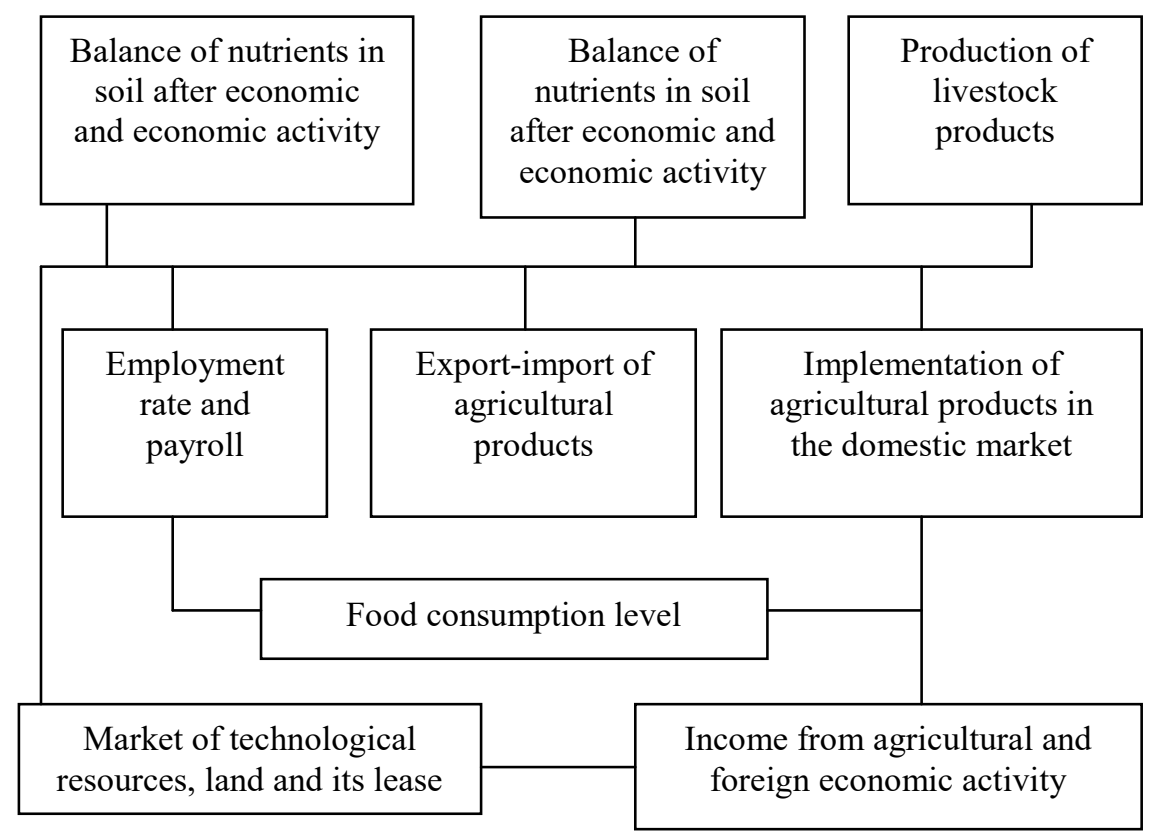

Fig. 1. The model of supply of the population of Ukraine with food at the macro-level. Source: developed by the authors. 
Here we clearly show the closed cycle for dairy of subcomplexes: "production - sale profit - recourses market including land market - consumption - expert - import employment level -production". The cycle closes up and the next cycle starts.

Aiming to discuss the problems of forming of food supply of the country or one of its regions, we shall consider the tendencies of dairy subcomplex parameters and the importance which it has in the other countries of the world. We remember of the world importance event for the countries specialized in dairy industry, namely: the Food and Agriculture Organization of the United Nations (FAO) and the International Dairy Federation (IDF) signed the Dairy Declaration of Rotterdam on 19 October, 2016. This Declaration is already signed by 20 national committees of IDF of the countries representing $45 \%$ of world production of milk. Dairy Management Consult, Doctor Jan Maarten Fray (Netherlands) pointed to world-scale importance of dairy cattle-breeding: sustainable development of dairy cattle-breeding provides direct or indirect profit to one milliard households engaged in dairy sector [6]. But this is almost a half a population of our planet if we consider that 3-4 people reside in each household.

Naturally, the countries of the world annually raise output of milk and dairy and cattle stock and bulls population. The situation and results of structural progress in the development strategies of the countries in the sphere of the dairy cattle-breeding are clearly demonstrated with the statistic grouping of the countries of the world according to consumption of grain for feeding of cattle and poultry (Fig. 2).

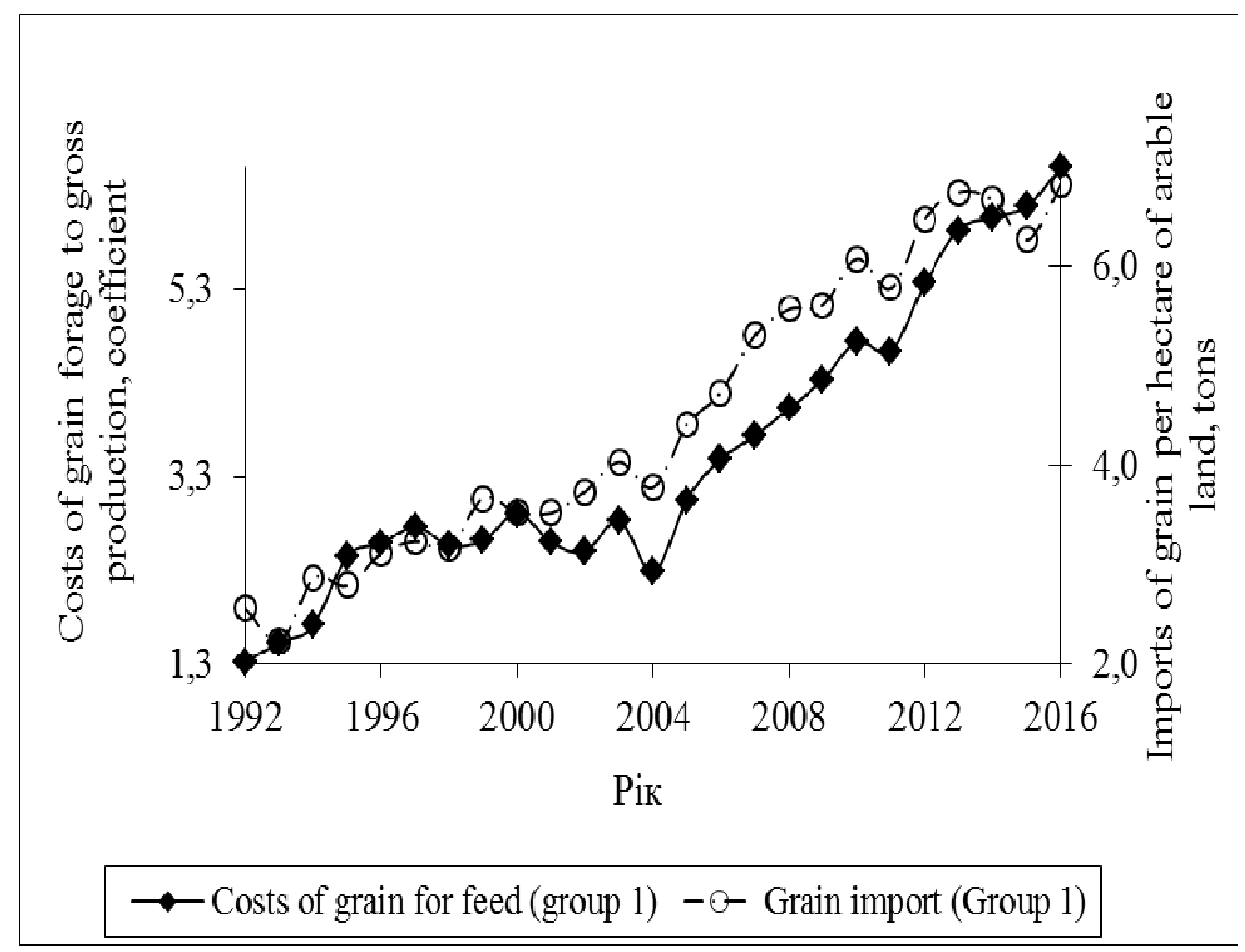

Fig. 2. Dynamics of grain importation and consumption for feeding of cattle and poultry relative to total output of grain in 1992-2018. Source: developed by the authors according to information of FAO [7].

The main result of market activity of the agrarian sector of the economy of Ukraine includes not only export component of the resources for the other countries. Such strategic direction of the country to production and exportation of grain and oil-yielding crops has 
one more section of the negative results of external economic activity. It is connected with the indexes of employment of population in agriculture and loss of nutrients (NPK) related to exportation of large volumes of crop production.

After structural progress in respect of strategic directions of development of Ukraine is was found that agriculture economically lags behind 82 countries of the world by tens or even hundreds times according to its specific indicators. Ukraine exporting grains and especially oil-yielding crops meals to the other countries, allows them rationally use concentrates for fodder using them in $2.5-3$ times less quantity per head of cattle, then Ukraine.

This is only one example from the whole group of negative results of strategy of development of agriculture in Ukraine. The next one includes output of organic fertilizers. Due to extremely low density of cattle and poultry population per 100ha of tillage (5-17 times less than in 82 countries of the world) we have the same indexes for output and possible application of fertilizers (5-15 time less, then in the first three groups of countries) -5 tons per 1 ha of tillage.

As we noted above, average consumption of dairy in terms of milk (without butter) is at the level of the group of countries importing grain and oil-yielding crops. But long-term strategy during the whole period of reformation after Ukraine obtained independence in respect of exportation of grain and oil-yield crops processing products resulted steady trend of worsening of provision of population with dairy (Fig. 3).

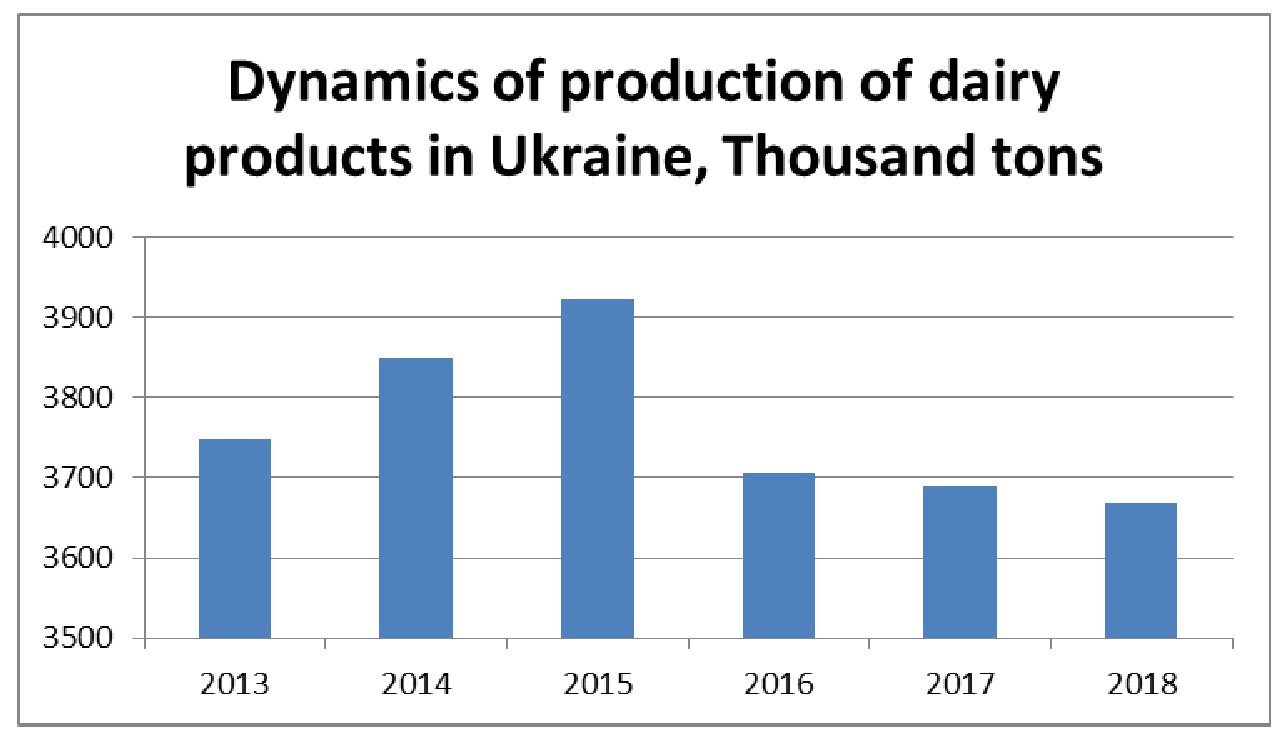

Fig. 3. Dynamics of production of dairy products in Ukraine from 2013 to 2018. Source: developed by the authors according to the information of the State Statistic Service of Ukraine for 2013-2019 [8].

The analysis proves that in the period of 2000-2018 80-95\% of population of Ukraine consumed dairy products under the physiological norm. And after 2006 this index is stable at the level of $88-92 \%$. Only in 2018 it reduced to $78 \%$.

Such sharp change of food prices in Ukraine causes reduction of consumption if the total revenues grow at much lower rates with further reduction of cattle population. Simultaneously, agricultural manufacturers and households will reduce cattle stock if in the chain of production, processing and trade the profits aggregate in the last links and 
producers suffer losses. Only such manner may be explained the fact, that the last 27 years of reformation of agriculture the sector of cattle breeding is permanently destructing.

So, as it is seen form the logical justification, the problem of destruction of cattlebreeding shall be considered according to 2 signs:

1) exceeding of the rate of rise in prices for food over the rate of total revenue of population;

2) existence of monopolism of trade in dairy subcomplex and lack of farmers cooperative vertical as opposition to monopolism in the technological and commercial chain from manufacturer to sale to consumers.

In the system "production -processing-consumption" the economic interest of various directions interweave. Thus, producers are interested in sale of milk as a raw material to processing plants for maximum price. These latters desire to buy raw material at minimum price and sale it to domestic consumers or exporters at maximum price. The consumers have their specific interests, first of all, they desire to buy quality and, to possible extent cheap products of milk plants. Also, interaction of the system "production -processing consumption" is regularly intervened by government and the various political forces. The government aims improvement of such interaction, but the politicians try to obtain political dividends. Such regular intervention of non-specialists into the complicated system without its thorough research has been causing the negative results.

We decided to study a simplified conditional milk plant which produces by turn one product - butter, then two ones (butter and further - dry milk from skim milk as the waste of mainline) and three ones (the previous ones were added production of normalized milk of $2.5 \%$ fat).

We shall note that the parameters of such extremely simplified milk plant with the limited range of products may be calculated without application of balance ideology. For example, from $1000 \mathrm{~kg}$ of milk (3.4\% fat) $46 \mathrm{~kg}$ of butter $(72.5 \%$ fat) and $904 \mathrm{~kg}$ of waste $(0.05 \%$ fat $)$ may be produced. And make further calculations at the current market the prices of raw milk, butter and waste and in respect of income distribution milk cost. The next variant - we add production of such product, as dry skim milk. Calculations with addition of production of several more milk products become very complicated and require application of the balance model. So, we shall apply to the balance methodology "inputoutput" for description of our simplified milk plant to understand how the prices form and learn the extent of objectiveness and effectiveness of the measures of the Antimonopoly Committee.

So, we can formulate two variants of integration of milk production, processing and sale of the ready products:

1) existing, when the high-capacity milk plants pay low prices for raw milk (at the level of low-capacity milk plants);

2) setting up farm cooperatives, agree the prices along the line from production to sale, what will provide their profitable operation.

According to the last variant, milk plans belonging to farm cooperatives will pay higher prices than is currently paid by monopolist milk plants. So, just exceeding of milk products prices rise rate over growth of total revenue of population, milk plants various abilities to pay for raw milk, lack of governmental regulation of prices or effective functioning of professional and inter professional organizations which promote negotiation on prices between the participants of integrated production make the basic causes of destruction of dairy cattle-breeding in Ukraine. Only production subsidies cannot solve the problems in the sector of dairy cattle-breeding, as these sums transfer to trade and processing enterprises through transfer of ownership over products. 


\section{Conclusions}

Analysis of retail prices and the levels of consumption of the basic dairy products, namely hard and soft cheese, cultured milk foods and butter proved that consumption of soft and hard cheese grew 1.2 times from 2006 to 2008 due to rise in price of raw material. The analysis of retail prices for the main kinds of dairy quite the contrary, showed reduction by $10 \%$. As a result, every year the prices exceed the incomes of population, including the income spent on food in respect of total revenue and remained unchanged by over $50 \%$ in situation that in this period the total revenues of the population quadrupled. At the same time, in the countries of the world according to Engel's law, as income rises, the proportion of income spent on food falls and they reached at their main part $10-20 \%$.

Setting of family farms will be successful if they create cooperatives which will be also engaged in sale of the final products through wholesale and/or retail trade. It will give the simultaneous structural changes in supply with dairy and the prospective of rise of incomes and level of employment of the rural population. Currently, Ukraine goes on with allotment of the budget funds for construction of very large dairy complexes (1000-5000 cows) by the holdings, but in 2018 the Ukrainian farmers were allotted 220 mil. grivnas subsidy for 8 dairy objects including 2 dairy complexes. We shall note, that just small-scale (for Ukraine) farms in EC, USA, Canada provided 10-160 time exceeding of export in calculation for 1 ha of tillage in comparison with Ukraine. The problem of growing of effectiveness of farming was solved by the West European countries, USA, Canada etc. by the way of consolidation of farmers into collective organizational and legal forms (scale effect is achieved).

\section{References}

1. P.T. Sabluk. New economic paradigm of formation of the strategy of national food security of Ukraine in the XXI century (2001)

2. M.V. Kuzubov, A. N. Edinak, N. L. Ovander. Modeling of economic and ecologicaleconomic processes (2010)

3. Y. M. Lopatinskiy. Influence of globalization of processes on the development of the domestic agricultural sector

4. M. M. Ilchuk. Effective functioning of milk product subcomplex of Ukraine (2004).

5. P. M. Gritsyuk. Problems of RACs. use the social-steward. and naturally-resource. potential of the region: fin. Policy and invest, 87-97 (2013).

6. J. M. Vrij. Why it is important for Ukrainian dairy to join the Dairy Declaration of Rotterdam. (2017).

7. Food and Agriculture Organization of the United Nations

8. State Statistics Service of Ukraine UPL:http://www.ukrstat.gov.ua/

9. V. Malchishnik. Own processing and creation of added value (2018)

10. The Georgian company revived the dairy business in Khmelnytsky UPL: http://km.sfs.gov.ua/media-ark/news-ark/251894.html

11. In Ukraine will open 60 family dairy farms UPL:https://ua.korrespondent.net/business/3488943-v-ukraini-vidkryuit-60-simeinykhmolochnykh-ferm. 